\title{
Kadar Lemak dan Air Pada Cookies dengan Substitusi Tepung Ubi Ungu dan Kacang Tanah
}

\author{
Nadia Karomatul Izza ${ }^{1}$, Nanik Hamidah, S. Gz, M. Gizi ${ }^{2}$, Dr Yahmi Ira S, STP, M. Si ${ }^{2}$ \\ ${ }^{1}$ Mahasiswa S1 Gizi STIKes Widya Cipta Husada \\ ${ }^{2,3}$ Dosen S1 Gizi STIKes Widya Cipta Husada \\ e-mail:nanikhamidah872@ gmail.com, nadiakaromatul@gmail.com, rasetyrum@ yahoo.co.id
}

\begin{abstract}
Cookies are crispy textured cakes. The main ingredient used to make cookies is wheat flour. Substitution of flour with purple sweet potato is done because purple sweet potato has content such as wheat flour. Purple yam flour contains amylose of $24.79 \%$ and amylopectin of $49.78 \%$. This research was conducted to analyze on fat level and water content in cookies. The study design was a Randomized Block Design. The treatment level was divided into 4 groups with the proportion of purple sweet potato flour: F0 (0\%: 0\%), F1 (55\%: 20\%), F2 (45\%: 30\%), and F3 (35\%: $40 \%$ ). Fat content analysis used was the soxhlet method. There was a significant effect $(\rho$ $=0,000$ ) on the amount of fat content in cookies. The highest fat content found in F3 was 38.85\%. Water content analysis used was the Thermogravimetric method. Statistical analysis of water content using friedmen with a reliability level of $95 \%$. There was a significant effect $(\rho=0,000)$ on the amount of water content in cookies. The lowest water content was in F3 of 38.85\%. The higher the addition of peanut flour, the lower the water content of cookies.
\end{abstract}

Keywords: Cookies, Purple Sweet Potatoes, Ground Peanuts, Fat Levels, Water Content

\section{PENDAHULUAN}

Cookies adalah kue berbahan dasar tepung terigu, yang bertekstur keras tapi renyah yang memiliki kadar air yang sangat rendah minimum $3,57 \%$ dan maksimum $5 \%$. Cookies adalah salah satu jenis biskuit yang dibuat dari adonan lunak, berkadar lemak tinggi minimum $24,72 \%$ relatif renyah bila dipatahkan dan penampang potongannya bertekstur padat.(Purnomo, 2007) Konsumsi rata rata cookies di Indonesia adalah 18.406 kg/tahun.(BPS, 2015) Penggunaan tepung terigu sebagai bahan baku pangan cenderung meningkat tiap tahunnya pada produk kue Indonesia. Konsumsi tepung terigu di Indonesia cenderung mengalami peningkatan, dari data BPS tahun 2016 sebesar 7,95 juta ton pada produk kue di Indonesia. Produksi tepung terigu sebanyak 4.855.261 ton.(BPS, 2015) Ketergantungan masyarakat Indonesia terhadap tepung terigu sangat tinggi, hal tersebut dapat dilihat dari konsumsi tepung terigu yang lebih banyak dari pada produksi tepung terigu.

Ubi jalar ungu merupakan komoditas ubi jalar yang banyak di tanam 
di Indonesia. Produksi ubi jalar di Kabupaten Malang pada tahun 2016 sebanyak 7.639 ton dan pada tahun 2017 meningkat sebanyak 11.165 ton.(BPS, 2015) Kandungan gizi ubi jalar ungu varietas antin-3 per 100 gram mengandung 150,7 miligram antosianin, 1,1\% serat, $18,2 \%$ pati, $0,4 \%$ gula reduksi, $0,6 \%$ protein, 0,70 miligram zat besi dan 20,1 miligram vitamin C. (Balitbangtan, 2016)

Ubi ungu termasuk pangan lokal yang mudah rusak, oleh karena itu ubi ungu perlu diolah lebih lanjut menjadi tepung. Hal ini bertujuan agar daya simpan lebih lama dan dapat dimanfaatkan sebagai bahan dasar cookies. Substitusi tepung terigu dilakukan karena ubi ungu mempunyai kandungan seperti tepung terigu. Pada tepung terigu mengandung amilosa sebesar 28\% dan amilopektin sebesar 72\%. Pada tepung ubi ungu mengandung amilosa sebesar $24,79 \%$ dan amilopektin sebesar 49,78\%.(Nindyarani, 2011)

Kandungan lemak pada ubi ungu tergolong rendah sekitar 0,329\%.(Balitbangtan, 2016) Pada cookies kandungan lemak minimal 24,72\%.(USDA, 2013) Berdasarkan hal tersebut perlu ditambahkan bahan untuk meningkatkan kandungan lemak yang ada pada cookies. Pada penelitian ini dipilih kacang tanah varietas Kelinci untuk meningkatkan kadar lemak pada cookies ubi ungu. Kacang tanah memiliki nilai gizi lemak tinggi (sebesar 47,7gr/100gr) dibandingkan dengan kacang yang lain (kacang kedelai mengandung lemak sebesar 18,0gr/100gr, dan kacang hijau mengandung lemak sebanyak 1,0gr/100gr).(Nindyarani, 2011) Kacang tanah merupakan salah satu sumber lemak yang cukup tinggi. Selain itu, potensi hasil panen kacang tanah cukup melimpah sekitar 4,3 t/ha polong kering. (Balitbangtan, 2016)

Pengujian kadar lemak dilakukan untuk mengetahui kadar lemak dalam cookies, mengingat bahan dasar yang digunakan merupakan bahan dasar yang tinggi lemak yaitu kacang tanah. Cookies subtitusi tepung ubi ungu dan tepung kacang tanah diharapkan dapat meningkatkan kadar lemak, karena dalam tepung kacang tanah mengandung lemak yang sangat tinggi 47,7gr/100gr yang bisa meningkatkan kandungan lemak pada cookies.(Notoadmojo, 2010) Penelitian terdahulu tentang pembuatan produk cookies dengan menggunakan subtitusi 
tepung kacang tanah menghasilkan lemak 25,1\%.(Purnomo, 2007) Kadar lemak pada cookies dipengaruhi oleh suhu yang digunakan serta lamanya waktu proses pengolahan. Makin tinggi suhu yang digunakan, maka kerusakan lemak akan semakin tinggi.

Pengujian kadar air dilakukan untuk mengetahui seberapa besar kadar air yang dihasilkan pada cookies yang disubtitusikan tepung ubi ungu dan tepung kacang tanah. Ubi ungu mengandung kadar air sebesar 7\% dan kacang tanah mengandung air 8\%. Kadar air suatu bahan pangan berpengaruh besar terhadap daya tahan bahan pangan, semakin tinggi kadar air maka semakin cepat terjadi kerusakan.(Purnomo, 2007) Faktor yang mempengaruhi kadar air pada cookies adalah pada proses pengovenan. Air berpindah dari tekanan tinggi ke tekanan rendah setelah proses pemanasan tetapi tidak semua air keluar dan menguap sehingga cookies masih mengandung kadar air dalam jumlah yang rendah.(Winarno, 2004)

Berdasarkan latar belakang di atas, peneliti melakukan penelitian tentang pengaruh subsitusi tepung ubi ungu dan tepung kacang tanah terhadap kadar lemak dan kadar air pada cookies.

\section{METODE PENELITIAN}

Penelitian ini merupakan penelitian True Experiment dengan Rancangan Acak Kelompok yaitu dengan 4 perlakuan proporsi tepung ubi ungu dan tepung kacang tanah F0 (0\%:0\%), F1 (55\%:20\%), F2 (45\%:30\%), F3 (35\%:40\%). Masing-masing perlakuan diulang sebanyak 6 kali. Analisis kadar lemak menggunakan metode Soxhlet. Kadar air menggunakan metode Thermogravimetri. Penggunaan total tepung pada cookies sebanyak 250 gram. F0 berarti tidak menggunakan tepung ubi ungu dan tepung kacang tanah. F1 menggunakan 137,5 gram tepung ubi ungu, 50 gram tepung kacang tanah, dan terigu 62,5 gram. F2 menggunakan 112,5 gram tepung ubi ungu, 75 gram tepung kacang tanah, dan terigu 62,5 gram. F3 menggunakan 87,5 gram tepung ubi ungu, 100 gram tepung kacang tanah, dan terigu 62,5 gram.

\section{Bahan dan Alat untuk membuat}

\section{produk dan Analisis Lemak}

Bahan untuk membuat produk adalah tepung ubi ungu, tepung kacang tanah, tepung terigu berprotein rendah, tepung ubi ungu, tepung kacang tanah, telur, susu bubuk, margarin, mentega, baking powder, vanilla essence dan gula halus. Alat yang digunakan timbangan, baskom, 
mixer, spatula, kuas, loyang, oven, sendok makan.

Bahan untuk analisis lemak yaitu 1 gram sampel. Alat yang digunakan antara lain oven, desikator, neraca analitik, kertas saring, tabung, dan labu soxhlet.

\section{Pembuatan Tepung Ubi Ungu}

Ubi ungu segar disortasi dan dipisahkan dari kotoran yang ada. Ubi ungu dikupas, lalu dicuci. Diris tipis lalu diletakkan pada loyang. Pengovenan dengan suhu $30-40^{\circ} \mathrm{C}$ selama 72 jam. Setelah kering dilakukan pengecekkan kadar air dari irisan kering ubi ungu yang diharapkan kadar air 10-10,5\%. Setelah kandungan kadar air terpenuhi maka dilakukan penggilingan dengan grinder ayakan 90 mesh.

\section{Pembuatan Tepung Kacang Tanah}

Biji kacang tanah direndam kedalam air mendidih selama 45 detik. Dikeringkan pada suhu $120^{\circ} \mathrm{C}$ dalam oven dengan aliran udara hingga kandungan airnya mencapai 5,9-6,4\%. Biji yang telah dioven, didinginkan, dihilangkan kulit arinya. Proses selanjutnya pengovenan kembali pada suhu $163^{\circ} \mathrm{C}$ sampai 20-30 menit, didinginkan lalu kacang tanah siap digiling.

\section{Pembuatan Cookies}

Menyiapkan semua bahan yang digunakan dan menimbang bahan sesuai dengan takaran. Menyiapkan semua alat yang diperlukan untuk pembuatan cookies. Timbang bahan kering seperti tepung kacang tanah, tepung ubi ungu, tepung terigu, dan susu bubuk.

Kemudian lemak (margarin dan mentega), gula, garam, dan bahan pengembang dicampur sampai terbentuk krim homogen menggunakan mixer. Tambahkan telur dan dikocok, kemudian ditambahkan vanilla essence, lalu tambahkan susu bubuk dan tepung terigu ditambahkan secara perlahan, dilakukan pengadukan sampai terbentuk adonan. Pengovenan dilakukan selama 25 menit dengan suhu $180^{\circ} \mathrm{C}-200^{\circ} \mathrm{C}$.

Pembuatan cookies dengan Rancangan Acak Kelompok yaitu Cookies dengan 24 sampel dilakukan pengovenan sebanyak 2 kali. Setiap kali pengovenan ada 12 loyang yang berisi formulasi F0, F1, F2 dan F3 dengan 3 kali pengulangan,

\section{Penyajian dan Analisis Data}

Data kadar lemak dan kadar air ditampilkan dalam bentuk mean $\pm \mathrm{SD}$. Uji normalitas dilakukan dengan uji Shapiro Wilk, jika p-value $\geq 0,05$ maka data 
terdistribusi normal, jika $\mathrm{p}$-value $<0,05$ maka data terdistribusi tidak normal. Analisis statistik yang digunakan untuk mengetahui pengaruh substitusi tepung ubi ungu dan tepung kacang tanah terhadap kadar lemak pada cookies dilakukan uji statistik two way anova pada tingkat kepercayaan 95\%, karena data terdistribusi normal. Uji lanjutan Duncan Multiple Test (DMRT) dilakukan untuk mengetahui taraf perlakuan mana yang berbeda nyata, pada tingkat kepercayaan 95\%. Uji Kruskal Wallis dilakukan untuk mengetahui kadar air karena data tidak terdistribusi normal. Selanjutnya untuk dapat secara rinci perlakuan mana yang berbeda nyata dilakukan dengan Mann Whitney. Software yang digunakan untuk mengetahui pengaruh proporsi tepung ubi ungu dan kacang tanah dalam pembuatan cookies yaitu SPSS 16.

\section{HASIL DAN PEMBAHASAN}

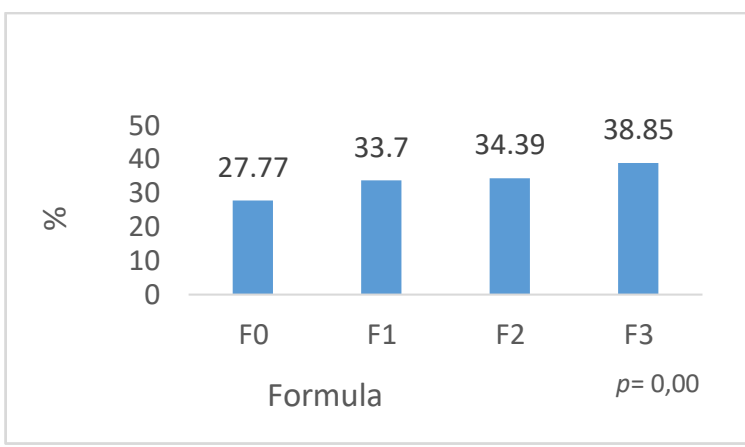

Gambar 4.2 Grafik Rata-rata Kadar Lemak

Cookies ( $\mathrm{p}=0,00$ menunjukkan ada pengaruh formulasi terhadap kadar lemak)

\section{Hasil Kadar Air}

Hasil rata-rata analisis kadar Air cookies bisa dilihat dalam Gambar 4.3.

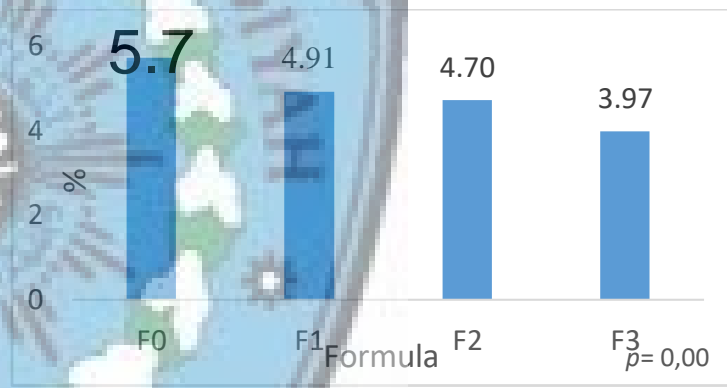

Gambar 4.3 Grafik Rata-rata Kadar Air

Cookies ( $\mathrm{p}=0,00$ menunjukkan ada pengaruh formulasi terhadap kadar lemak)

\section{Hasil Kadar Lemak}

Hasil rata-rata analisis kadar lemak cookies bisa dilihat dalam Gambar 4.2.

\section{Uji Kadar Lemak}

Hasil uji statistik two way anova pada tingkat kepercayaan $95 \%$ berdasarkan ulangan atau replikasi menunjukkan tidak terdapat pengaruh yang signifikan $(\rho=0,493)$ terhadap jumlah kadar lemak pada cookies. Hasil dari perlakuan atau formulasi pada cookies menunjukkan terdapat pengaruh 
yang signifikan $(\rho=0,000)$ terhadap kadar lemak pada cookies. Hasil uji lanjutan menggunakan Duncan Multiple Range Test (DMRT) menunjukkan bahwa jumlah kadar lemak paling tinggi pada perlakuan F3.

Standart kadar lemak cookies yang baik adalah cookies yang mencapai minimum 24,72\% dikatakan cookies yang memenuhi syarat mutu cookies USDA (2018). Pada perlakuan F0 (27,77\%), F1 $(33,70 \%), \mathrm{F} 2(34,39 \%)$ dan F3 $(38,85 \%)$.

Keempat perlakuan memenuhi karakterisistik cookies menurut USDA (2018) yaitu $\geq 24,72 \%$.

Perlakuan F3 menghasilkan kadar lemak yang paling tinggi dibandingkan F0 (kontrol), F1 dan F2. Tingginya kadar lemak pada F3 disebakan proporsi tepung kacang tanah lebih tinggi yaitu $40 \%$ dibandingkan dengan perlakuan yang lain. Seiring dengan bertambahnya proporsi tepung kacang tanah pada perlakuan cookies maka kadar lemak semakin meningkat. Hal ini disebabkan kadar lemak yang terkandung pada tepung kacang tanah lebih besar dibandingkan tepung ubi ungu, tepung kacang tanah mengandung lemak sebesar 47,70 g/100g. ${ }^{9}$ Hal ini sejalan dengan hasil penelitian pada cookies dengan menggunakan tepung ubi kayu, tepung garut dengan penambahan tepung kacang tanah akan meningkatkan kadar lemak yang tinggi sebesar 25,10\% dalam pembuatan biskuit. Hal ini membuktikan bahwa semakin tinggi penambahan tepung kacang tanah maka kadar lemak semakin meningkat, mengingat kadar lemak kacang tanah tinggi yaitu 47,70 gr.(Notoadmojo, 2010)

Kadar lemak dalam penelitian ini untuk perlakuan F0-F3 mencapai 27-38\% diharapkan mampu memenuhi tingkat kecukupan lemak di Indonesia. Berdasarkan data secara nasional tingkat kecukupan lemak per orang perhari paling rendah pada kelompok umur 0-59 bulan (41,90 gram), diikuti kelompok umur >55 tahun $(43,40$ gram) dan tertinggi pada kelompok umur 512 tahun (56,80 gram) dan kelompok umur 13-18 tahun (56,7 gram). Berdasarkan angka kecukupan gizi (AKG, 2013) pada usia 19-25 tahun kebutuhan gizi lemak dalam sehari untuk perempuan sebesar 75 gram dan untuk laki-laki sebesar 91 gram. Konsumsi persajian cookies dapat menyumbangkan lemak sebesar $4,13 \%$ pada perempuan, sedangkan untuk laki laki dalam satu konsumsi cookies lemak tercukupi sebesar $3,40 \%$.

\section{Uji Kadar Air}

Hasil uji statistik two way anova pada tingkat kepercayaan $95 \%$ berdasarkan 
ulangan atau replikasi menunjukkan tidak terdapat pengaruh yang signifikan $(\rho=0,493)$ terhadap jumlah kadar lemak pada cookies. Hasil dari perlakuan atau formulasi pada cookies menunjukkan terdapat pengaruh yang signifikan $(\rho=0,000)$ terhadap jumlah kadar lemak pada cookies.

Standart kadar air cookies yang baik adalah cookies yang mencapai minimum 3,57\% dan maksimum 5\% telah memenuhi syarat mutu cookies USDA, (2018). Pada perlakuan F0 $(5,70 \%)$, F1 $(4,91 \%), \quad$ F2 $(4,70 \%)$ dan F3 $(3,97 \%)$. Keempat perlakuan memenuhi karakterisistik cookies menurut USDA (2018) yaitu $\geq 3,57 \%$.

Perlakuan F3 menghasilkan jumlah kadar air yang paling rendah dibandingkan F0 (kontrol), F1 dan F2, karena proporsi tepung kacang tanah lebih tinggi yaitu $40 \%$ dibandingkan dengan perlakuan yang lain. Hal ini menunjukkan semakin tinggi subtitusi tepung kacang tanah maka semakin rendah kadar air pada cookies, karena pada kacang tanah banyak mengandung protein dan protein tersebut bisa menyerap air pada cookies saat proses pengovenan. Penyerapan air diakibatkan adanya gugus karboksil pada protein, sehingga semakin tinggi kandungan protein dalam cookies maka teksturnya cenderung kurang renyah dan kadar airnya rendah. ${ }^{10}$ Protein mempunyai sifat hidrofilik yaitu mempunyai daya serap air yang tinggi. Hal ini disebabkan karena dengan semakin tinggi dan lamanya pengeringan (oven) maka molekul air yang menguap dari adonan cookies yang dikeringkan semakin banyak dan bagian air bebas yang terdapat dipermukaan bahan dapat dengan mudah diuapkan pada proses pengeringan sehingga kadar air yang diperoleh semakin rendah. Semakin tinggi suhu dan lama waktu pengeringan maka semakin besar energi panas yang dibawa udara sehingga jumlah massa cairan yang diuapkan dari permukaan cookies semakin banyak. Semakin rendah kadar air maka akan memperpanjang daya simpan pada cookies.(Lestari, 2018)

\section{KESIMPULAN DAN SARAN}

\section{KESIMPULAN}

Berdasarkan hasil penelitian dapat disimpulkan bahwa:

1. Terdapat pengaruh proporsi substitusi tepung ubi ungu dan tepung kacang tanah terhadap kadar lemak pada cookies. Formulasi tinggi yaitu perlakuan F3 Proporsi (tepung ubi ungu : tepung kacang tanah $=35 \%: 40 \%$ ) sebesar $38,85 \%$. 
2. Terdapat pengaruh proporsi substitusi tepung ubi ungu dan tepung kacang tanah terhadap kadar air pada cookies. Formulasi rendah yaitu perlakuan F3 Proporsi (tepung ubi ungu : tepung kacang tanah $=35 \%: 40 \%$ ) sebesar $3,97 \%$.

\section{SARAN}

Perlu dilakukan uji jumlah energi dan kadar karbohidrat subsitusi tepung ubi ungu dan tepung kacang tanah pada cookies.

\section{UCAPAN TERIMAKASIH}

Penulis mengucapkan terima kasih kepada semua pihak yang telah membantu penelitian ini.

\section{DAFTAR PUSTAKA}

Balitbangtan (Balai Penelitian dan Pengembangan Pertanian). (2016). "Ubi jalar Antin 1, Antin 2 dan Antin 3: Kaya Antosianin", (Online). http://new.litbang.pertanian.go.id/info -teknologi/2648/, diakses pada 15 Maret 2018).

BPS (Badan Pusat Statistik). (2015). Data Statistika Pertanian Tanaman Pangan Data Statistik Konsumsi Makanan Olahan Tepung Terigu. Jakarta.

Lestari, T.I., Nurhidajah, N, dan Yusuf M. 2018. Kadar Protein, Tekstur dan Sifat Organoleptik Cookies yang Disubstitusi Tepung Ganyong (Canna edulis) dab Tepung Kacang Kedelai (Glycine max L.). Semarang: Jurnal Pangan dan Gizi. Program Studi S1 Teknologi Pangan Fakultas Ilmu Keperawatan dan Kesehatan Universitas Muhammadiyah Semarang. https://jurnal.unimus.ac.id/index.php/J PDG/article/view/3361.

Murtiningsih, Latifa, Andriyani. (2013). Kajian kualitas biskuit jagung. Jurnal Rekapangan. Vol. 1, No. 7. http://www.ejournal.upnjatim.ac.id/ind ex.php/teknologipangan/article/download/489/387.

Nindyarani, A.K., Sutardi, dan Suparmo. (2011). "Karakteristik Kimia, Fisik dan Inderawi Ubi Jalar Ungu (Ipomoea batatas P.) dan Produk Olahannya". Jurusan Teknologi Pangan dan Hasil Pertanian Universitas Gadjah Mada.

Notoatmodjo. (2010). Metodologi Penelitian Kesehatan. Jakarta: PT. Rineka cipta.

Purnomo dan Purnamawati, H. (2007). Budidaya dan Jenis Tanaman Pangan Unggul. Jakarta: Penebar Swadaya.

Purnomo. (2007). Budidaya dan Jenis Tanaman Pangan Unggul. Jakarta: Penebar Swadaya.

Sabrina, Z.U., Susanto, W.H. (2017). "Pengaruh Suhu dan Lama Pengeringan dengan Metode Cabinet Dryer Terhadap Karakteristik Manisan Kering Apel Varietas Anna (Malus Domestica Borkh)". Jurnal Pangan dan Agroindustri. Vol. 5, No. 3. http://www.jpa.ub.ac.id/index.php/jpa/ article/download/545/398. 
USDA. (2013). National Nutrient Data Base for Standard. Basic Report 20649, Tapioca, pearl, dry. The national Agriculutural Library.

Winarno, F. (2004). Kimia Pangan dan Gizi. Jakarta: Gramedia. Pengolahan Universitas Gadjah Mada. Yogyakarta.

Yulifianti. (2013). "Teknologi pengolahan dan produk olahan kacang tanah.", (online).

(file:///G:/PROYEK\%20AKIR\%20TE PUNG\%20UBI\%20UNGU/pengolaha n\%20kacang\%20tanah\%20!!.pdf, diakses 3 April 2019). 